\title{
Diversity of Ants (Hymenoptera: Formicidae) In Urban Forest Fragment of Cuiabá-MT
}

\author{
${ }^{1}$ Maria T C Carvalho, ${ }^{2}$ Alberto Dorval, ${ }^{3}$ Otávio Peres Filho, ${ }^{4}$ Marcelo D de Souza, ${ }^{5}$ Lilian G de Favare, ${ }^{1}$ Josamar G da Silva \\ Junior $^{1}$
}

${ }^{1}$ Master's Degree Program in Forestry and Environmental Sciences (PPGCFA).UFMT, Cuiabá - Brazil.

${ }^{2}$ Professor in the area of Ecology of insects.Faculdade de Engenharia Florestal - FENF/UFMT, Cuiabá - Brazil.

${ }^{3}$ Titular Professor - Forest Entomology Area, FENF/UFMT, Cuiabá - Brazil.

${ }^{4}$ Professor in Environmental Engineering, of Universidade de Cuiabá. Cuiabá - Brazil.

${ }^{5}$ PhD student in the National Postdoctoral Program, PPGCFA/UFMT. Cuiabá - Brazil.

Correspondence Author: Lilian Guimarães de Favare, Postgraduate in Forestry and Environmental Sciences (PPGCFA - UFMT). Cuiabá - Brazil. E-mail: lilianfavare@hotmail.com

Received date: 12 June 2018, Accepted date: 4 September 2018, Online date: 13 September 2018

Copyright: (C) 2018 Maria T C Carvalho, et al, This is an open-access article distributed under the terms of the Creative Commons Attribution License, which permits unrestricted use, distribution, and reproduction in any medium, provided the original author and source are credited.

\begin{abstract}
The urban forest fragments are composed of a housing matrix and constitute, for fundamental reasons, the portion of preservation of diversity and efficiency for the relationship between living beings and the environment. The survey of the diversity of ants of a fragment has the function of being the picture of the situation of the assessed environment, be it permanent or transitory. The objective of this work was to identify the diversity of ants, in an urban forest fragment according to the levels of anthropization of the fragment, in the city of Cuiabá/MT. The environments were classified as Cerrado native, transition zone and anthropic Cerrado, and for each environment 15 Pitfall traps were arranged, from which they were distributed in a transect equidistant 20 meters, remaining in the field seven days a month. The collected entomological material was sent to the Forest Protection Laboratory of the Faculty of Forestry Engineering, Universidade Federal de Mato Grosso, at each collection, to perform the taxonomic and genotypic identification and species identification. Faunistic analyses were performed, such as: wealth index, diversity, equity and similarity of Sorenson. To compare the diversity among the environments, the means of occurrence of the species were compared statistically by the Tukey test at the $5 \%$ probability level. The composition of ant species diversity can be influenced by the state of conservation of the environment. It was observed in the study that Solenopsis sp., Solenopsis invicta, Atta sexdens, Labidus praedator, Pheidole jelskiiand, Pheidole obscurithorax were representative in the faunistic analysis, due to the maximum classifications obtained in the items that compose the index. The analysis of variance for the number of species collected showed that there was no significant difference between the transition and anthropic environments, whereas for the number of individuals, there was no difference between the native and anthropic environments in the dry period. The advancement of anthropization in forest fragments favours their colonization by species of omnivorous and opportunistic ants.
\end{abstract}


Key words: Ant fauna, anthropization, species richness, burlap.

\section{INTRODUCTION}

The urban forest fragments are remnants of forest, natural vegetation immersed in urban matrix (Melo et al., 2011). In general, urban forest fragments are isolated, reduced areas that suffer high anthropogenic pressures (Dacanal et al., 2010). The process of fragmentation is considered to be the most harmful, especially on non-generalist fauna, which depends on the shape, size and degree of disturbance to determine its survival (Terborgh, 1992). According to Dátillo et al. (2011), the anthropic action in the urban forest fragments can negatively influence the ant community, since the collected specimens are characterized as being common in disturbed and open environments. The ease in sampling, high abundance, distribution and functioning of ecosystems, besides being sensitive to environmental changes, and relatively well known taxonomy, make the formicideos increasingly suggested as indicators of the condition of conservation of the area (Agosti et al., 2000).

Formicideos are eusocial insects characterized by a high degree of social organization. They are present in almost all the terrestrial ecosystems (Gonzalez, 2006), representing around $40 \%$ of the biomass (Holldobler and Wilson, 1990), is composed of seventeen subfamilies, 39 tribes, 334 genera, 13,235 species and 1,961 subspecies (Bolton, 2014). This group of insects plays important ecological functions, since they are predators of diverse arthropods and other species of ants. Although some species are considered agricultural pests (Fowler et al., 1991), this act as seed dispersers, incorporate organic matter into the environment and participate in the soil aeration process (Peternelli, 2004).

According to Holldobler and Wilson (1990), generally, the foraging and establishment of the colony are restricted to a given microhabitat, where the individual characteristics of the species are influenced by variations in temperature, humidity and resource availability. Its food habit is diversified in order to facilitate the exploration of many terrestrial ecosystems. Vasconcelos and Delabie (2000) they observed that forest fragmentation does not significantly affect the species richness of ants, but affects their composition, with a tendency to change in fragments smaller than three hectares.

Santos et al. (2006) explain that apparently the local richness of ants in fragments is associated with the diversity of available habitats and other factors that would act on a local scale, such as the physical structure and quantity of burlap, where there is availability and variety of food resources and nesting sites. Vasconcelos et al. (2001) found twice as many species in the forest fragment compared to savanna, and in both environments, the occurrence of species in the soil was higher than in the vegetation. Gomes et al. (2010) verified that in the dynamics of the ant communities, the richness is more affected by the conservation degree of the vegetation than by the size of the forest fragments.

The survey of the diversity of ants in this fragment serves as an evaluation of the situation of the area, since these are considered ideal models in biodiversity studies, giving information to infer about the level of anthropization of the forest fragment, since they are insects sensitive to anthropogenic activities (Gomes $e t$ al. 2014). Therefore, the objective of this work was to identify the diversity of ants in an urban forest fragment, according to the levels of anthropization of the fragment, in the city of Cuiabá/MT.

\section{MATERIAL AND METHODS}

The study was carried out in an urban forest fragment, in the city of Cuiabá / MT, under the coordinate's $15^{\circ} 34^{\prime} 5^{\prime \prime S}$ e $56^{\circ} 6^{\prime} 28^{\prime \prime} \mathrm{W}$. The total area of the fragment is approximately 117 ha, considered as a Damping Zone in the Park Management Plan. According to Köppen classification, the climate is tropical continental type, warm and semi-humid, with two seasons defined as rainy season (spring and summer) and dry season (autumn and winter). The annual rainfall varies from 1,250 to $1,500 \mathrm{~mm}$ and the annual average relative humidity is $69.9 \%$ (Duarte, 2003).

To perform the entomological survey, the area was sub classified in environments. It was observed the level of anthropic impact, promoted by the activities of the non-forested matrix on the urban forest fragment, establishing a gradient of degradation, being:

Native Environment - In this forest fragment, the structure of vegetation is dense, with trees with an average of 7 meters to 15 meters of height, in good conservation condition. The upper stratum is closed, with greater shading in the understory. Soil entirely covered by litter and visible absence of anthropization;

Transition Environment -The arboreal individuals with a little less than $6 \mathrm{~m}$ of height, whose distribution is of more spaced form. Less dense crowns where shading is not promoted, occurrence of vegetation in natural regeneration, in the early stages with vestiges of human presence.

Anthropic Environment -This environment is characterized by the high degree of anthropization and changes in the landscape, few arboreal individuals and predominance of grasses and vegetation in the early stages.

Pitfall traps were used, consisting of plastic containers of $15 \mathrm{~cm}$ height and entrance hole $2.5 \mathrm{~cm}$ in diameter, filled with water, neutral detergent and salt, buried with their edges being at ground level (Aquino, 2006). The traps were covered with plastic plates of $15 \mathrm{~cm}$ in diameter, allowing the capture of the ants and protecting entry of water (rain) and vegetable remains.

Within each environment, the amount of 15 traps arranged in transect of $300 \mathrm{~m}$, whose trapping interval was $20 \mathrm{~m}$, remained in the field for seven days / month. The collections occurred in the period of six months, three months (February to April, 2016), corresponding to the rainy season and three months (July to September 2016) corresponding to the dry period. 
The collected entomological material was sent to the Forest Protection Laboratory, Faculty of Forestry Engineering, Universidade Federal do Mato Grosso, at each collection, to carry out the sorting and separation of individuals, packed in containers with $70 \%$ alcohol, to await identification step. The taxonomic identification was performed by Dr. Jacques Hubert C. Delabie - Laboratory of Myrmecology of the Cocoa Research Center, Ilhéus / BA.

Fauna studies as an index of wealth (Margaleff Wealth), Diversity Index (Shannon-Wiener), Equity Index (known as Hill's Reason Modified) (Ludwing and Reynolds, 1998) and Sorenson's Index (qualitative index), these analyses being calculated by software ANAFAU (Moraes et al., 2003).

\section{RESULTS AND DISCUSSION}

In the three environments, 19,217 individuals were collected, Table 1 shows that 8,792 were collected only in the transition environment, considered the most expressive (46\%), being observed the occurrence of five subfamilies, Myrmicinae with fourteen (39\%, more abundant in individuals) and Formicinae eleven species (30\%), both as the most diverse already Dolichoderinae and Ponerinae with five species each (14\%), and Dorylinae only one (3\%).

In terms of feeding habit, among 36 species recorded, twenty predators (33.33\%), three fungus cultivators (8.33\%) and one granivore (2.78\%) were among the 36 species registered. In Dolichoderinae all the species sampled are omnivorous, in Ponerinae all species are predators, whereas in Formicinae, the predominant feeding habits were omnivores and predators. The Myrmicinae representative species were heterogeneous in relation to the food preference.

Analysing the food habit of the species by environment, in the native, thirteen species were omnivorous (54.17\%), nine predators (37.50\%) and two fungus cultivators $(8.33 \%)$, in the transition area, fifteen were omnivorous (53.57\%), ten predators (35.71\%), two fungus cultivators (7.14\%) and one granivore (3.57\%).In the anthropogenic environment, thirteen omnivorous species (50\%), ten predators (38.46\%), two fungus cultivators (7.67\%) and one granivore $(3.85 \%)$.With highlight Solenopsis sp.2 (60.82) omnivorous species with highest percentage of individuals collected in total sum of the study; and Solenopsis invicta with the second highest percentage, however, collected only in the anthropic environment.

Among the fourteen species collected from Myrmicinae, three were unique to the native environment, Pheidole group fallax sp.1, Pheidole radoszkowskii and Pheidole fimbriata. The high Pheidole diversity in the area may be indicative of conserved area as a characteristic hyper diversity genus for wide distribution and expansion. According to Marinhoet al. (2002), it is expected the occurrence of Pheidole group fallax in native environment, because they are species originating from the Cerrado.

In the transition environment, five species were unique, P. termitarius, B. conops (Myrmicinae), C. Tanaemyrmex (Formicinae), F. brasiliensis (Dolichoderinae) and L. praedator (Dorylinae). According to Quinet et al. (2009), L. praedator, characterized by being opportunistic and generalist populations in relation to nesting, but are more restrictive in feeding habits, since they are predators. The species D. brunneum and S. invicta occurred only in the anthropic environment. Dorymyrmex is a genus of omnivorous ant generalist, found exclusively in the Americas (Fernández, 2003).

Among the subfamilies, Myrmicinae with fourteen species and Formicinae with eleven, were the ones that presented larger quantities of species common to the studied environments. The occurrence of high diversity of Myrmicinae species is justified because it is numerically the largest and most diverse subfamily of ants in the Neotropical region, being characterized by being one of the most abundant ant groups, with ease of adaptation to different ecological niches, besides of several species present a high degree of social complexity (Brandão and Cancello, 1999; Fernández, 2003).

Formicinae are represented by cosmopolitan species, with a tendency to reduce size and occupation of microhabitats, with several species of generalist and predatory non-specialized habit, and can colonize different environments, regardless of their state of preservation, but as a function of availability and abundance of food for the colony (Holldobler and Wilson, 1990).

The occurrence of Brachymyrmex sp.1 in a native and anthropic environment and C. myrmaphaenus, also omnivorous, with a common occurrence between the transition and anthropogenic environments, corroborates the above authors' assertions that these species are few influenced by the state of preservation of the place, but by the food supply.

Formicinae, Myrmicinae and Ponerinae with eight, six and three species, respectively, were the most representative subfamilies in the quantity of species common to the three environments.

B. admotus, B. heeri, Brachymyrmex sp.2, C. crassus, C. fustigatus, C. melanoticus, were the representative species Formicinae. The presence of Camponotus in the three environments is justified by the fact that it has less restrictive or omnivorous feeding habits (Wilson, 1997) and because of its wide geographic distribution. Several species of this genus can feed on liquid diet and maintain a mutual association with several species of homopterous (Fowler et al., 1991). According to Macedo (2006), these have great potential for invasion of new areas and adaptation to interact with other organisms, guaranteeing the capacity of dissemination.

W. auropunctatais unique to the neotropical region, its workers are small and nest in the burlap. Considered an opportunistic species with high adaptive capacity in altered environments (Silvestre et al., 2003), its bioecology is little known, but it is known that its food habit is predatory (Brady et al., 2014). Species common to the three environments it is suggested that there was food supply, independent of the anthropization gradient of the fragment.

According to Brady et al. (2014), Solenopsis are predominantly omnivorous, usually small ants that occupy, preferably, the interior of the burlap, rarely leaving in search of food (Silvestre, 2003). Justifying by the ease in adaptation in the different environments, Pheidole is well diversified, they are fed of products rich in proteins (Bueno and Campos-Farinha, 1999). For Silvestre et al. (2003), Pheidole species are also characterized by opportunistic and generalist populations in relation to nesting because they build their nests in places such as rotting branches and trunks of trees, in the soil, in mounds of organic matter, under rocks and / or associated with the roots of plants. 
110

Citation: Maria T C Carvalho, et al., Diversity of Ants (Hymenoptera: Formicidae) In Urban Forest Fragment of Cuiabá-Mt. Australian Journal of Basic and Applied Sciences, 12(9): 107-115. DOI: 10.22587/ajbas.2018.12.9.18

Seen as ants of economic impact, according to Santos and Del-Klaro (2002), the cuttings of the genus Atta have a specific nutritional habit, foraging long distances in the search for leaves to feed fungi, justified by the symbiosis process, however, even though it occurred in all three environments, there was a preference for the native environment, probably determined by the supply of fungus-favourable resources.

Table1: Survey of formicideos with feeding habit, quantity of anybody (A) and respective percentage (\%) in the urban forest fragments sampled.

\begin{tabular}{|c|c|c|c|c|c|c|c|}
\hline \multirow{2}{*}{ Subfamily/Species } & \multirow{2}{*}{ Feeding Habits } & \multicolumn{2}{|c|}{ Native } & \multicolumn{2}{|c|}{ Transition } & \multicolumn{2}{|c|}{ Anthropized } \\
\hline & & $\mathbf{A}$ & $\%$ & $\mathbf{A}$ & $\%$ & $\mathbf{A}$ & $\%$ \\
\hline \multicolumn{8}{|l|}{ Dolichoderinae } \\
\hline Dorymyrmex sp.1 & Omnivores & 1 & 0,03 & 51 & 0,58 & - & - \\
\hline Dorymyrmex brunneus (Forel, 1908) & Omnivores & - & - & - & - & 101 & 1,34 \\
\hline Dorymyrmex bicolor (Wheeler, W.M., 1906) & Omnivores & - & - & 24 & 0,27 & 116 & 1,53 \\
\hline Forelius brasiliensis (Forel, 1908) & Omnivores & - & - & 16 & 0,18 & - & - \\
\hline Gracilidris pombero (Wild \&Cuezzo, 2006) & Omnivores & - & - & 24 & 0,27 & 1 & 0,01 \\
\hline \multicolumn{8}{|l|}{ Dorylinae } \\
\hline Labidus praedator (Fr. Smith, 1858) & Predatory & - & - & 1959 & 22,28 & - & - \\
\hline \multicolumn{8}{|l|}{ Formicinae } \\
\hline Brachymyrmex sp.1 & Predatory & 1 & 0,03 & - & - & 29 & 0,38 \\
\hline Brachymyrmex sp.2 & Predatory & 1 & 0,03 & 50 & 0,57 & 30 & 0,40 \\
\hline Brachymyrmex admotus (Mayr, 1887) & Predatory & 5 & 0,17 & 441 & 5,02 & 146 & 1,93 \\
\hline Brachymyrmex heeri (Forel, 1874) & Predatory & 3 & 0,10 & 21 & 0,24 & 4 & 0,05 \\
\hline Camponotus crassus (Mayr, 1862) & Omnivores & 246 & 8,60 & 112 & 1,27 & 28 & 0,37 \\
\hline Camponotus fastigatus (Roger, 1863) & Omnivores & 23 & 0,80 & 48 & 0,55 & 19 & 0,25 \\
\hline Camponotus myrmaphaenus (Emery, 1920) & Omnivores & - & - & 29 & 0,33 & 2 & 0,03 \\
\hline Camponotus melanoticus (Emery, 1894) & Omnivores & 123 & 4,30 & 172 & 1,96 & 28 & 0,37 \\
\hline Camponotus rufipes (Fabricius, 1775) & Omnivores & 56 & 1,96 & 59 & 0,67 & 10 & 0,13 \\
\hline Camponotus tanaemyrmex (Ashmead, 1905) & Omnivores & - & - & 5 & 0,06 & - & - \\
\hline Camponotus vittatus (Forel, 1904) & Omnivores & 95 & 3,32 & 13 & 0,15 & 29 & 0,38 \\
\hline \multicolumn{8}{|l|}{ Myrmicinae } \\
\hline Atta sexdens (Linnaeus, 1758) & Fungivorous & 606 & 21,18 & 59 & 0,67 & 12 & 0,16 \\
\hline Blepharidatta conops (Kempf, 1967) & Fungivorous & - & - & 14 & 0,16 & - & - \\
\hline Crematogaster victima (Smith, F., 1858) & Omnivores & 70 & 2,45 & 19 & 0,22 & 48 & 0,63 \\
\hline Cyphomyrmex prox. Lectus & Fungivorous & 7 & 0,24 & - & - & 3 & 0,04 \\
\hline Pheidole group fallax sp.1 & Omnivores & 175 & 6,12 & - & - & - & - \\
\hline Pheidole fimbriata (Roger, 1863) & Omnivores & 132 & 4,61 & - & - & - & - \\
\hline Pheidole jelskii (Mayr, 1884) & Omnivores & 1 & 0,03 & 22 & 0,25 & 176 & 2,33 \\
\hline Pheidole obscurithorax (Naves, 1985) & Omnivores & 171 & 5,98 & 187 & 2,13 & 170 & 2,25 \\
\hline Pheidole radoszkowskii (Mayr, 1884) & Omnivores & 1 & 0,03 & - & - & - & - \\
\hline Pogonomyrmex abdominalis (Santschi, 1929) & Granivore & - & - & 12 & 0,14 & 23 & 0,30 \\
\hline Pseudomyrmex termitarius (Smith, F., 1855) & Predatory & - & - & 35 & 0,40 & - & - \\
\hline Solenopsis sp. 2 & Omnivores & 1091 & 38,13 & 5348 & 60,83 & 2121 & 28,04 \\
\hline Solenopsis invicta (Buren, 1972) & Omnivores & - & - & - & - & 4350 & 57,51 \\
\hline Wasmannia auropunctata $($ Roger, 1863$)$ & Predatory & 40 & 1,40 & 3 & 0,03 & 38 & 0,51 \\
\hline \multicolumn{8}{|l|}{ Ponerinae } \\
\hline Ectatomma brunneum (Smith, F., 1858) & Predatory & 2 & 0,07 & 16 & 0,18 & 28 & 0,37 \\
\hline Ectatomma permagnum (Forel, 1908) & Predatory & 2 & 0,07 & 19 & 0,22 & 26 & 0,34 \\
\hline Odontomachus bauri (Emery, 1892) & Predatory & 8 & 0,28 & 22 & 0,25 & 18 & 0,24 \\
\hline Odontomachus brunneus (Patton, 1894) & Predatory & - & - & 12 & 0,14 & 2 & 0,03 \\
\hline Pachycondyla harpax (Fabricius, 1804) & Predatory & 1 & 0,03 & - & - & 6 & 0,08 \\
\hline Number of individuals per environment & & 2861 & 100 & 8792 & 100 & 7564 & 100 \\
\hline
\end{tabular}


E. brunneum, E. permagnum and O. bauri, preferred transition and anthropic environments, although they were present in the three environments. Lattke (2003) states that they inhabit dry forests, with seasonal rainfall; however, they are more frequent in rainforest areas and sampled environments, with the exception of the native area, are drier environments, associated with less occurrence of individuals of this subfamily in this work.

Species of the genus Ectatomma have generalist and opportunistic habits (Brown Junior, 1958), often in response to resource constraints, skilled workers enter neighbouring colonies and steal food collected by them (Guénard and Mcglynn, 2013).

According to Brady et al. (2014), Odontomachus possesses predatory habit ants that occur in all tropical regions and hot areas of temperate regions, from arid to humid forests, with a unique jaw closure mechanism in Ponerinae, known as the 'jaw-trap'. Foraging is solitary and among the main prey are soft-bodied arthropods, especially termites. Numerically, it occurred in a larger number of individuals collected in the transition environment, but it does not differ significantly from the amount of individuals in the anthropic environment, most probably because of these environments, better to offer food resources.

The species D. brunneus, D. bicolor, F. brasiliensis, G. pombero and C. myrmaphaenus are omnivorous, and this food habit can justify its occurrence in transition and anthropic environments, environments with diverse food supply caused by the anthropic impact.

Naturally occurring in cerrado, Brachymyrmex species forage in the soil, litter and sensitive to changes in their habitat tend to decrease their density in anthropogenic areas. However, even in the anthropic areas of the fragment, Brachymyrmex occurred in a larger number of individuals than in the native environment.

The species common to the native and anthropic environments were Brachymyrmex sp. 1 (predator), Cyphomyrmex prox. Lectus (fungus cultivator), and $P$. harpax (predator). Dorymyrmex sp.1 was common to native and transitional environments. It is observed that the food habits of these, were more specific, $P$. harpax are generalist predators and occasionally feed on seeds in the forest soil and with a highly elaborated recruitment strategy (Baccaro et al., 2015), while ants of the genus Cyphomyrmex live in the burlap and during foraging collect a wide variety of items for the cultivation of the symbiotic fungus, such as flowers, fruits, seeds, insect feces, lichens, mosses and arthropod carcasses (Leal and Oliveira, 1998).

In this study, 17 species of ants occurred in all the evaluated environments, being of the subfamilies Formicinae, Myrmicinae and Ponerinae. Among them are Solenopsis sp2, E. brunneum, C. crassu and P. obscurithorax with relevant characteristics.

According to Bueno and Campos-Farinha (1999) the distribution and population density of Solenopsis sp2 is regulated by the presence of predators, parasitoids and pathogens, as well as competition with other species of ants. E. brunneum, widely distributed in Latin America, colonizing areas of forest that are conserved until pasture is considered a generalist predator (Delabie et al., 2000), but also can feed on extra floral nectary (Del-Claro et al., 1992), explaining its occurrence in the evaluated environments.

C. crassus are mostly omnivorous, opportunistic, and actively foraging the demand for food, thus inhibiting the foraging of other species (Silvestre and Silva, 2001), explaining, the representativeness of this species. In the Tietê region, according to Suguituru et al. (2015), was widely recorded in herbaceous, arboreal, burlap, squares and urban parks, suggesting that the species may be indicative of altered environments. P. obscurithorax, omnivorous species and predators of a wide variety of arthropods, including other ants, have elaborate foraging tactics and nests are constructed in open areas (Storz and Tschinkel, 2004).

The highest population densities in the native environment were represented by Solenopsis sp. (38.13\%) and A. sexdens (21.18\%). A. sexdens had its highest number of individuals collected in the native environment, which is contrary to Bieber et al. (2006), because according to these authors, high densities of colonies of this species occur generally on forest edges.

In the anthropic environment, S. invicta (57.51\%) and Solenopsis sp. (28.04\%) were more expressive in amounts of individuals sampled. According to Kaspari (2003), S. invicta is characterized by presenting many queens and many nests, consequently dominate the habitats by virtue of its great potential of growth and spatial extension. Solenopsis sp2.was present in an expressive way, but was more evident in the transition environment, certainly because the species is native to South America, more specifically the Pantanal and Cerrado.

Seasonality in the diversity of ants:

Seasonality effects on the number of individuals collected, composition and species richness were observed in the sample months (Table 2), thus agreeing with Holldobler and Wilson (1990) that the change in temperature, soil and air humidity create restrictions for different species of ants, as it influences their reproduction, distribution and survival.

In the dry period, in the native environment, there were sixteen species distributed in 638 individuals collected. Camponotus with four, Pheidole with three, Brachymyrmex with two and Ectatomma with two, were the most representative genera in quantity of species. The species Solenopsis sp. with 269, P. jelskii with 149, P. obscurithorax with 91 and A. sexdens with 58 were the most expressive quantitatively.

In the transition environment, 25 species and 5,412 individuals were collected during the dry period. The most diversified genera were the genera Camponotus with six species, Brachymyrmex with three, while Solenopsis, Brachymyrmex, Camponotus and Pheidole were responsible for the largest number of individuals, Solenopsis sp. with 4.516, B. admotus with 228 and P. obscurithorax with 159.

In the anthropic environment, 24 species were collected, distributed among 1,183 individuals. Camponotus with six and Dorymyrmex with three, were the genera with the largest quantities of species. The genus Solenopsis with 474, Pheidole with 324, Brachymyrmex with 132 and Dorymyrmex with 123 were the most expressive in quantity of individuals collected, being the most representative species, Solenopsis sp. with 461, P. obscurithorax with $165, P$. jelskii with $159, B$. admotus with 132 .

Among the most expressive species in the number of individuals collected, in relation to seasonality (dry period), were found in the native environment, Solenopsis sp. and P. jelskii; in the transition environment the most expressive with $83.44 \%$ was Solenopsis sp; the species Solenopsis sp., P. obscurithorax and $P$. jelskii were the highlight of the dry period.

The species of the genus Gracilidris constitute small colonies with nocturnal foraging habits, are apparently generalists nesting in the forest soil with low vegetation in the cerrado (Baccaro et al., 2015), the occurrence of this species in these two environments was higher in the dry period, suggesting that the habit of nocturnal foraging allowed this result even in the period of high temperatures.

In the rainy season nineteen species occurred in the native environment, Camponotus with five and Pheidole with four species. In relation to the number of individuals collected, Solenopsis with 822, Atta with 548, Camponotus with 503 and Pheidole with 239 were the most expressive genera. The most representative species in individuals were Solenopsis sp. with 822, A. sexdens with 548, C. crassus with 240, P. fimbriata with 132 and C. melanoticus with 120.

In the transition environment, the occurrence of 23 species, Camponotus with six was the most diversified genus in species. Labidus with 1.959, Solenopsis with 832, Brachymyrmex with 240 and Camponotus with 206 were the most expressive genera in amounts of individuals collected. The occurrence of $L$. praedator with 1.959. Solenopsis sp. with 832 and B. admotus with 213 were the species with the highest amounts of individuals collected in the period in this environment.

It is noteworthy that the L. praedator species occurred restrictively in the rainy season and in the transition environment. According to Monteiro (2008) $L$. praedator seems to choose nesting sites that would eventually be subject to flooding, temporary nesting sites, basing the occurrence of this species only in the rainy season. 
In the anthropic environment, 24 species occurred, being Camponotus with five, Brachymyrmex and Dorymyrmex with three each, the genres in focus. Their species with the greatest number of individuals collected were S. invicta with 4,337, Solenopsis sp. with 1,660 and D. bicolor with 76.

Among the species with the most significant differences in the number of individuals collected in relation to the seasonality (rainy season) in the native environment, we have Solenopsis sp and A. sexdens; in the transition environment the species L. praedator and Solenopsis sp; already for the anthropized environment the species S. invicta and Solenopsis sp. It is observed that the species constant in the fragment, and that did not suffer as far as the seasonality was Solenopsis sp. which remained in the area in a constant way, with almost exponential change in the evaluations in the transition environment as a function of the dry period (83.44\%), being the largest register of individuals collected throughout the evaluation period of the urban fragment area. According to Silvestre (2003) some ants occupy extremely unfavorable environments, such as those that have been altered anthropically, places that suffer periodic flooding, lack of oxygen, places with long periods of exposure to radiation and chemicals, with exceptional adaptation.

Dorymyrmex occur frequently in anthropogenic environments, they are extremely fast ants, they forage in isolation and are often found during the hottest hours of the day, avoiding competition with species more sensitive to heat, although some species feed on honeydew produced by sucking insects of sap (Baccaro et al., 2015). It was observed in the native environment the quantitative difference of individuals of $A$. sexdens, occurring in the rainy season, it is justified, therefore, the seasonality in influence to the physiological activity of the plants, with new shoots, where the leafy ants go in search of the food for cultivating your fungi symbionts. For Fagundes et al. (2009) seasonal variations of ant specimens during the seasons may be due to food availability, specific behaviors such as nomadic food storage habits and habitat specificity can determine the permanence of a species during and after the variation of local atmospheric conditions.

Table2: List of subfamilies and number of anybody by species, in the dry and rainy periods, in the urban forest fragments sampled.

\begin{tabular}{|c|c|c|c|c|c|c|}
\hline \multirow{2}{*}{ Subfamily/Species } & \multicolumn{3}{|c|}{ Dry period } & \multicolumn{3}{|c|}{ Rainy period } \\
\hline & $\mathbf{N}$ & $\mathbf{T}$ & An & $\mathbf{N}$ & $\mathbf{T}$ & An \\
\hline \multicolumn{7}{|l|}{ Dolichoderinae } \\
\hline Dorymyrmex sp.1 & - & 23 & 7 & 1 & 29 & 22 \\
\hline Dorymyrmex brunneus (Forel, 1908) & - & 13 & 40 & - & 11 & 76 \\
\hline Dorymyrmex bicolor (Wheeler, W.M., 1906) & - & - & 76 & - & - & 25 \\
\hline Forelius brasiliensis (Forel, 1908) & - & 16 & - & - & - & - \\
\hline Gracilidris pombero (Wild \& Cuezzo, 2006) & - & 21 & - & - & 3 & 1 \\
\hline \multicolumn{7}{|l|}{ Dorylinae } \\
\hline Labidus praedator (Fr. Smith, 1858) & - & - & - & - & 1.959 & - \\
\hline \multicolumn{7}{|l|}{ Formicinae } \\
\hline Brachymyrmex sp.1 & - & - & - & 1 & - & - \\
\hline Brachymyrmex sp.2 & - & 22 & 7 & 1 & 27 & 23 \\
\hline Brachymyrmex admotus (Mayr, 1887) & 5 & 228 & 132 & - & 213 & 14 \\
\hline Brachymyrmex heeri (Forel, 1874) & 3 & 21 & - & - & - & 4 \\
\hline Camponotus crassus (Mayr, 1862) & 6 & 73 & 12 & 240 & 39 & 16 \\
\hline Camponotus fastigatus (Roger, 1863) & 4 & 22 & 12 & 19 & 26 & 7 \\
\hline Camponotus myrmaphaenus (Emery, 1920) & - & 16 & 2 & - & 13 & - \\
\hline Camponotus melanoticus (Emery, 1894) & 3 & 82 & 22 & 120 & 90 & 6 \\
\hline Camponotus rufipes (Fabricius, 1775) & - & 26 & 1 & 56 & 33 & 9 \\
\hline Camponotus tanaemyrmex (Ashmead, 1905) & - & - & - & - & 5 & - \\
\hline Camponotus vittatus (Forel, 1904) & 27 & 13 & 1 & 68 & - & 28 \\
\hline \multicolumn{7}{|l|}{ Myrmicinae } \\
\hline Atta sexdens (Linnaeus, 1758) & 58 & 30 & 8 & 548 & 29 & 4 \\
\hline Blepharidatta conops (Kempf, 1967) & - & 13 & - & - & 1 & - \\
\hline Crematogaster victima (Smith, F., 1858) & 6 & 9 & 10 & 64 & 10 & 38 \\
\hline Cyphomyrmex prox. Lectus & 7 & - & 3 & - & - & - \\
\hline Pheidole group fallax sp.1 & 1 & - & - & - & - & - \\
\hline Pheidole fimbriata (Roger, 1863) & - & - & - & 132 & - & - \\
\hline Pheidole jelskii (Mayr, 1884) & 149 & 22 & 159 & 22 & - & 17 \\
\hline Pheidole obscurithorax (Naves, 1985) & 91 & 159 & 165 & 84 & 28 & 5 \\
\hline Pheidole radoszkowskii (Mayr, 1884) & - & - & - & 1 & - & - \\
\hline Pogonomyrmex abdominalis (Santschi, 1929) & - & 6 & 5 & - & 6 & 18 \\
\hline Pseudomyrmex termitarius (Smith, F., 1855) & - & 35 & - & - & - & - \\
\hline Solenopsis sp.2 & - & - & 13 & - & - & 4.337 \\
\hline Solenopsis invicta (Buren, 1972) & 269 & 4.516 & 461 & 822 & 832 & 1.660 \\
\hline Wasmannia auropunctata (Roger, 1863$)$ & 6 & - & 5 & 34 & 3 & 33 \\
\hline \multicolumn{7}{|l|}{ Ponerinae } \\
\hline Ectatomma brunneum (Smith, F., 1858) & 2 & 13 & 19 & - & 3 & 9 \\
\hline Ectatomma permagnum (Forel, 1908) & 1 & 18 & 18 & 1 & 1 & 8 \\
\hline Odontomachus bauri (Emery, 1892) & - & 5 & 5 & 8 & 17 & 13 \\
\hline Odontomachus brunneus (Patton, 1894) & - & 10 & - & - & 2 & 2 \\
\hline Pachycondyla harpax (Fabricius, 1804) & - & - & 6 & 1 & - & - \\
\hline Total & 638 & 5.412 & 1.189 & 2.223 & 3.380 & 6.375 \\
\hline
\end{tabular}

$\mathrm{N}=$ native; $\mathrm{T}=$ transition; $\mathrm{An}=$ anthropized 
Citation: Maria T C Carvalho, et al., Diversity of Ants (Hymenoptera: Formicidae) In Urban Forest Fragment of Cuiabá-Mt. Australian Journal of Basic and Applied Sciences, 12(9): 107-115. DOI: 10.22587/ajbas.2018.12.9.18

In the analysis of the communities, it was observed that the diversity index was relatively higher in the rainy season in the native and transition environments, indicating a better population distribution of the species when compared to the anthropic environment, which was better in the dry period (Table 3).

Table 3: Diversity index (Hill number series) and equitability of ant species sampled in an urban forest fragment.Cuiabá - Brazil, 2016.

\begin{tabular}{|c|c|c|c|c|c|c|c|c|c|}
\hline \multirow{3}{*}{ Items } & \multicolumn{9}{|c|}{ Environments/Periods } \\
\hline & \multicolumn{3}{|l|}{ Native } & \multicolumn{3}{|c|}{ Transition } & \multicolumn{3}{|c|}{ Anthropized } \\
\hline & Dry & Rainy & Total & Dry & Rainy & Total & Dry & Rainy & Total \\
\hline $\mathrm{N}_{0}$ & 16 & 18 & 24 & 25 & 23 & 28 & 23 & 24 & 27 \\
\hline $\mathrm{N}_{1}$ & 5.32 & 6.63 & 7.23 & 2.40 & 3.89 & 3.92 & 7.65 & 2.56 & 3.79 \\
\hline $\mathrm{N}_{2}$ & 3.81 & 4.55 & 4.73 & 1.42 & 2.48 & 2.36 & 4.81 & 1.88 & 2.43 \\
\hline $\mathrm{H}^{\prime}$ & 1.67 & 1.81 & 1.97 & 0.87 & 1.35 & 1.36 & 2.03 & 0.94 & 1.33 \\
\hline $\mathrm{E}$ & 0.65 & 0.63 & 0.59 & 0.30 & 0.51 & 0.45 & 0.57 & 0.56 & 0.51 \\
\hline $\mathrm{B}$ & 0.26 & 0.21 & 0.21 & 0.69 & 0.40 & 0.42 & 0.20 & 0.53 & 0.41 \\
\hline A & 2.32 & 2.20 & 2.88 & 2.79 & 2.70 & 2.97 & 3.10 & 2.62 & 2.91 \\
\hline
\end{tabular}

$\mathrm{N}_{0}=$ total number of species; $\mathrm{N}_{1}=$ number of abundant species; $\mathrm{N}_{2}=$ Number of very abundant species; H' $=$ Shannon-Wiener; E=Equity between species; $\beta=$ Simpson's Index; $\alpha=$ Margaleff's Wealth Index.

Analyzing the total period, the native environment presented the greatest diversity of species $\left(\mathrm{H}^{\prime}=1.97\right)$, followed by the transition environment $\left(\mathrm{H}^{\prime}=1.36\right)$ and anthropized $\left(H^{\prime}=1.33\right)$ by Margaleff's index, it was observed that the results were different in relation to the Shannon index, since the highest obs erved value was in the transition environment $(\alpha=2.97)$, followed by $(\alpha=2.91)$ and anthropized $(\alpha=2.88)$. Such a difference is explained because diversity reflects two basic attributes of community, species richness and equitability, which corresponds to the distribution of individuals within populations (Ludwig and Reynolds, 1988). Thus, the Shannon index considers all species of the sample, however, it assigns differentiated weights to the rare, abundant and abundant species, which is ignored by many indexes of wealth used, such as the Margalef index, and it is still possible to perceive that the native environment presented more abundant and abundant species.

In another study, Thomazini and Thomazini (2000) state that, after fragmentation and a certain period of isolation, there is an increase in wealth as a result of the invasion of other species associated with modified habitats, according to Vasconcelos (2001), these changes in forest structure seem to favor the species associated to disturbed environments, to the detriment of the typical species of the interior of the forest.

In the native environment, regardless of the period analyzed, there has always been greater equitability among ant species, indicating that the environment is the ecologically more balanced and more equitable distribution of the food resource. The relationship between very abundant and abundant species indicates distribution in the most homogeneous population densities, which hinders the dominance of a few species.

\section{Sorenson Similarity Index:}

Regarding the similarity, the Sorenson Index indicates the formation of distinct groups within the analyzed environments, since it ranged from 0.5 to 0.79 , and the variation is from 0 to 1 , where when closer to 1 , higher is the similarity between the sampled environments. It can be observed in the results of the total analysis (Table 4), a greater similarity between the environments with native and anthropic vegetation (0.77), while in the dry and rainy periods, the transition and anthropic environments were the most similar. Although all environments showed little difference in terms of species composition, this may have occurred due to the presence of large numbers of generalist and opportunistic ants in the environments studied.

For Laurance and Vasconcelos (2009), the similarity is inversely proportional to the vegetation development, as the trees grow, provide more niches for different species of ants, thus an environment with no or low human intervention when compared to similarity with other environments, the tendency is to present a lower similarity index value.

Species accumulation curve:

Through the analysis of the accumulation curve (Figure 1), it was observed that the transition environment and the anthropic environment were more similar to each other when compared to native, a fact demonstrated through the stabilization of the curve, although these areas are still suffering strong influences in the environment, due to the anthropic effects that were submitted. However, it is expected that these areas will be recovered with ecological stability, so that they will be re - colonized by a greater diversity of resident ant species, without species dominance and with little variation of feeding habit.

In the native environment, curve stabilization did not occur due to the enormous diversity of species that explore a multiplicity of nesting resources and sites (Leponce et al., 2004), which favors the creation of the ideal environment for the occurrence of greater diversity of forms, eating habits, varied, and do not fit in a few months as observed in transitional and anthropized environments. Therefore, in order to obtain reliable information on the richness of myrmecofauna in this type of environment, a larger sampling effort is necessary to stabilize the species accumulation curve.

Table 4: Similarities between three environments of an urban forest fragment. Cuiabá - Brazil, 2016.

\begin{tabular}{|c|c|c|c|c|}
\hline \multirow{2}{*}{ Period } & \multicolumn{4}{|c|}{ Environments } \\
\hline & & Native & Transition & Anthropized \\
\hline \multirow{3}{*}{ Dry } & Native & - & 0.63 & 0.66 \\
\hline & Transition & - & - & 0.79 \\
\hline & Anthropized & - & - & - \\
\hline \multirow{3}{*}{ Rainy } & Native & - & 0.50 & 0.69 \\
\hline & Transition & - & - & 0.75 \\
\hline & Anthropized & - & - & - \\
\hline
\end{tabular}




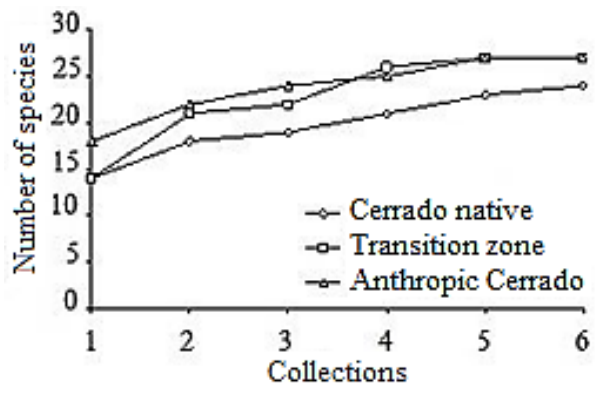

Fig. 1: Accumulation curve of ant species in three forest environments of an urban fragment sampled with pitfall traps. Cuiabá - Brazil, 2016.

Conclusion:

The level of anthropization influences the occurrence of species, as well as the number of individuals, due to the smaller amount of large vegetation of which decreases the alternating shading so the climatic conditions that are the factors that influence the occurrence of the ants, influenced by local seasonality.

\section{REFERENCES}

Agosti, D.J., Majer, L.E. Alonso, R. Schultz, 2000. Ants: Standard methods for measuring and monitoring biodiversity. Washington, D.C.: Smithsonian Institution Press, 2000. <http://antbase.org/databases/publications_files/publications_20330.htmegt> Access 4 May 2018.

Aquino, A.M., E.L. Aguiar-Menezes, J.M. Queiroz, 2006. Recomendação para coleta de artrópodes terrestres por armadilhas de queda (pitfalltraps). Seropédica: Embrapa Agrobiologia, (Circular Técnica, 18).

Baccaro, F., R.M. Feitosa, F. Fernandez, I.O. Fernandes, T.J. Izzo, J.L.P. de Souza, R. Solar, 2015. Guia para os gêneros de formigas do Brasil. Manaus: Editora INPA, 338p. <https://www.researchgate.net/profile/Fabricio_Baccaro/publication/283791449_Guia_para_os_generos_de_formigas_do_Brasil/links/5647 328608ae451880ac05e5/Guia-para-os-generos-de-formigas-do-Brasil.pdf> Access 2 Mar 2018.

Bieber, A.G.D., K.L. Porto, M. Tabarelli, J. Almeida-Cortez, 2006. Diversidade biológica e conservação da Floresta Atlântica ao norte do rio São Francisco. Recife, Editora Universitária da UFPE, pp: 363.

Bolton, B., 2014. An online catalogue of the ants of the world. <http://antcat.org> Access 20 Mar 2018.

Brady, S.G., B.L. Fisher, T.R. Schultz, P.S. Ward, 2014. The rise of army ants and their relatives: diversification of specialized predatory dorylinae ants. BMC Evolutionary Biology, 14(1): 93.

Brandão, C.R.F. and E.M. Cancello, 1999. Invertebrados Terrestres. In: Joly, C.A., E.M. Cancello, (Org.). Biodiversidade do Estado de São Paulo: síntese do conhecimento ao final do século XX. São Paulo, FAPESP. 1999, 279 p. 〈http://www.mma.gov.br/estruturas/chm/_arquivos/Aval_Conhec_Cap4.pdf>. Access 7 Mar 2018.

Brow Junior, W.L., 1958. Contributions toward a reclassification of the Formicidae. II. Tribe Ectatomminae (Hymenoptera) Bulletin of the Museum Comparative Zoology, 118: 173-362.

Bueno, O.C. and A.E.C. de Campos-Farinha, 1999. As formigas domésticas - Insetos e outros invasores de residências. Piracicaba: FEALQ, pp: 135-180.

Dacanal, C., L.C. Labaki, T.M.L. Silva, 2010. Vamos passear na floresta! O conforto térmico em fragmentos florestais urbanos. Ambiente Construído, Porto Alegre, 10(2): 115-132.

Del-Claro, K., M.A. Pizo, P.S. Oliveira, 1992. Competição e hierarquia de dominância entre espécies de formigas se utilizando de nectários extraflorais de Urena aff. lobata L. (Malvaceae). In: X Encontro Anual de Etologia, Jaboticabal, 10, Resumos.

Delabie, J.H.C., D. Agosti, I.C. do Nascimento, 2000. Litter ant communities of the Brazilian Atlantic rain forest region. In: Agosti, D., J.D. Majer, T. Schultz. (Ed.). Sampling Ground-dwelling Ants: Case Studies from the World's Rain Forests.

Duarte, D.H.S. and G.G. SERRA, 2003. Padrões de ocupação do solo e microclimas urbanos na região tropical continental Brasileira: correlações e proposta de um indicador. Ambiente Construído, Porto Alegre, 3(2): 7-20.

Fagundes, R., N.B.E. Santos, G.L. Silva, A.C.R. Maia, J.F.L. Santos, S.P. Ribeiro, 2009. Efeito das mudanças climáticas sazonais no forrageio de Formigas em uma área de mata estacional semidecidual Montana. In: Congresso De Ecologia Do Brasil, 9, São Lourenço - MG. Anais... São Lourenço.

Fowler, H.G., L.C. Forti, C.R.F. Brandão, J.H.C. Delabie, H.L. Vasconcelos, 1991. Ecologia nutricional de formigas. In: Panizzi, A.R., J.R.P. Parra(Ed.). Ecologia nutricional de insetos e suas implicações no manejo de pragas. São Paulo: Manole.

Guénard, B. and T.P. Mcglynn, 2013.Intraspecific thievery in the ant Ectatomma ruidum is mediated by food availability. Biotropica, 45(4): 497-502.

Gomes, J.P., L. Iannuzzi, I.R. Leal, 2010. Resposta da comunidade de formigas aos atributos dos fragmentos e da vegetação em uma paisagem da floresta atlântica nordestina. Neotropical Entomology 39: 898-905.

Gonzalez, V.H., 2006. Introducción a las hormigas de la regiónNeotropical. Revista Colombiana de Entomologia. 32(1): 100.

Holldobler, B. and E.O. Wilson, 1990. The ants. Cambridge: Havard University Press.

Kaspari, M., 2003.Introducción a la ecologia de las hormigas. In: F. Fernández (Ed.). Introducción a las hormigas de la región Neotropical. Bogotá, Instituto de Investigación de Recursos Biológicos Alexander von Humboldt.

Laroca, S. and O.H.H. Mielke, 1975. Ensaio sobre ecologia de comunidade em Sphingidea na Serra do Mar, Paraná-BR (Lepidoptera). Revista brasileira de biologia, Rio de Janeiro, 35(1): 1-19.

Lattke, J.E., 2003. Subfamília Ponerinae. In: F. Fernández, (Ed.). Introducción a las hormigas de la región Neotropical. Bogotá-COL: Instituto de Investigación de Recursos Biológicos Alexander Von Humboldt.

Laurance, W.F. and H.L. Vasconcelos, 2009. Consequências ecológicas da fragmentação florestal na Amazônia. OecologiaBrasiliensis, 13(3): 434-451.

Leal, I.R. and P.S. Oliveira, 1998.Interactions between fungus growing ants (Attini), fruits and seeds in cerrado vegetation in Southeast Brazil. Biotropica, 30: $170-178$.

Leponce, M., L. Theunis, J.H.C. Delabie, Y. Roisin, 2004. Scale dependence of diversity measures in a leaf-litter ant assemblages. Ecography, $27: 253-267$.

Ludwing, J.A. and J.F. Reynolds, 1988.Stastical ecology a primer on methods and computing a Wiley-interscience publication. NewYork. 
Macedo, L.P.M., E. Berti Filho, J.H.C. Delabie, 2006. Diversidade de formigas edáficas (Hymenoptera: Formicidae) associadas àEuterpe edulisvonMartius (Arecaceae), em diferentes formações vegetais do bioma Mata Atlântica em São Paulo, Brasil. Revista de Agricultura, 81: 55-70.

Marinho, C.G.S., R. Zanetti, J.H.C. Delabie, M.N. Schlindwein, L. de S. Ramos, 2002. Diversidade de formigas (Hymenoptera: Formicidae) da serapilheira em eucaliptais (Myrtaceae) e área de cerrado de Minas Gerais. Neotropical Entomology, 31(2): 187-195.

Melo, G., J. Sponchiado, A.F. Machado, N.C. Cáceres, 2011. Small-mammal community structure in a South American deciduous Atlantic Forest. Community Ecology, 12(1): 58-66.

Monteiro, A.F.M.E., P.H. Togni, E.R. Suji, 2008. Biologia de Labidus coecus em agroecossistema de tomateiro orgânico no Distrito Federal. Congresso Brasileiro de Zoologia, 2008.

Moraes, R.C.B., M.L. Haddad, S. Silveira Neto A.E.L. Reyes, 2003. Software para análise faunística. In: Simpósio de Controle Biológico, 8, São Paulo. Resumos. Piracicaba-SP. ESALQ.

Peternelli, E.F.O., T.M.C.E. Della-Lucia, S.V. Martins, 2004. "Espécies de formigas que interagem com as sementes de Mabea fistulifera Mart. (Euphorbiaceae). Revista Árvore, 28: 733-738.

Quinet, Y., R. Hamidi, M.X. Ruiz-Gonzalez, J.C. de Biseau, J.T. Longino, 2009. Crematogaster pygmaea (Hymenoptera: Formicidae: Myrmicinae), a highly polygynous and polydomous Crematogaster from northeastern Brazil. Zootaxa, 2075: 45-54.

Sakagami, S.F., S. Laroca, J.S. Moure, 1967. Wild bee biocenotics in São José dos Pinhais (PR), south Brazil. Preliminary report. J. Fac. Sci. Hokkaido Univ. Ser. VI, Zool. 16(2): 253-291.

Santos, J.C. and K. Del-Claro, 2002. As formigas tecelãs do cerrado. Ciência Hoje, São Paulo, 32 (188): 68-71.

Santos, M.S., J.N.C. Louzada, N. Dias, R. Zanetti, J.H.C. Delabie, I.C. do Nascimento. 2006. Riqueza de formigas (Hymenoptera: Formicidade) da serapilheira em fragmentos de floresta semidecídua da Mata Atlântica na região do Alto do Rio Grande, MG, Brasil. Ilheringia, ser. Zool, Porto Alegre, 96(1).

Silvestre, R. and R.R. Silva, 2001. Guildas de formigas da Estação Ecológica Jataí, Luiz Antônio - SP - sugestões para aplicação do modelo de guildas como bio-indicadores ambientais. Biotemas 14: 37-69.

Silvestre, R., C.R.F. Brandão, R.R. Silva, 2003. Grupo funcionales de hormigas: el caso de los grêmios del Cerrado. In: FERNÁNDEZ F. (Ed.). Introducción a las hormigas de La región Neotropical. Bogotá: Instituto de Investigación de Recursos Biológicos Alexander von Humboldt.

Storz, S.R. and W.R. Tschinkel, 2004. Distribution, spread and ecological associations of the introduced ant Pheidole obscurithorax in the southeastern United States.Journal of Insect Science, 4(1): 12.

Suguituru, S.S., M.S.C. Morini, R.M. Feitosa, R.R. Silva, 2015. Formigas do Alto Tietê. Bauru: Canal, 6: 456. 〈http://canal6.com.br/formigas/>. Access 7 Mar 2018.

Terborgh, J., 1992. Maintenance of diversity in tropical forests. Biotropica. 24: 283-292.

Thomazini, M.J. and A.P.B.W. Thomazini, 2000. A fragmentação florestal e a diversidade de insetos nas florestas tropicais úmidas. Embrapa Acre. Documentos.

Ulloa, P.C., 2003. Hormigas urbanas. In: F. Fernández (ed.). Introducción a las hormigas de la región neotropical. Bogotá: Instituto de investigación de recursos biológicos Alexander von Humboldt.

Vasconcelos, H.L., 2001. Diversidade de formigas cortadeiras no Brasil. In: XV Encontro de Mirmecologia, Londrina. Anais... do XV Encontro de Mirmecologia. Londrina: Editora do Instituto Agronômico do Paraná (IAPAR).

Vasconcelos, H.L. and J.H.C. Delabie, 2000. Ground ant communities from central Amazonia forest fragments. Sampling Ground-Dwelling Ants: Case Studies from the World's Rain Forests, 18: 59-70.

Wilson, E.O., 1997. Naturalista. Rio de Janeiro: Nova Fronteira. 